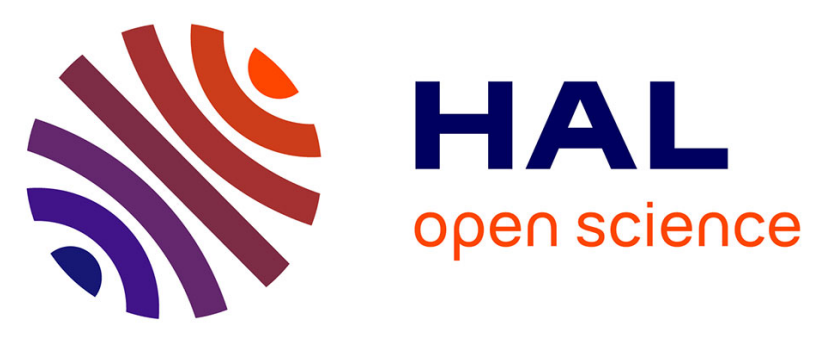

\title{
Distribution and sequence analysis of a family of type III-dependent effectors correlate with the phylogeny of Ralstonia solanacearum strains
}

\author{
M. Lavie, B. Seunes, Philippe Prior, C. Boucher
}

\section{- To cite this version:}

M. Lavie, B. Seunes, Philippe Prior, C. Boucher. Distribution and sequence analysis of a family of type III-dependent effectors correlate with the phylogeny of Ralstonia solanacearum strains. Molecular Plant-Microbe Interactions, 2004, 17 (8), pp.931-940. 10.1094/MPMI.2004.17.8.931 • hal-02683276

\section{HAL Id: hal-02683276 \\ https://hal.inrae.fr/hal-02683276}

Submitted on 1 Jun 2020

HAL is a multi-disciplinary open access archive for the deposit and dissemination of scientific research documents, whether they are published or not. The documents may come from teaching and research institutions in France or abroad, or from public or private research centers.
L'archive ouverte pluridisciplinaire HAL, est destinée au dépôt et à la diffusion de documents scientifiques de niveau recherche, publiés ou non, émanant des établissements d'enseignement et de recherche français ou étrangers, des laboratoires publics ou privés.

\section{다(1)(2)}

Distributed under a Creative Commons Attribution - ShareAlikel 4.0 International 


\title{
Distribution and Sequence Analysis of a Family of Type III-Dependent Effectors Correlate with the Phylogeny of Ralstonia solanacearum Strains
}

\author{
Muriel Lavie, ${ }^{1}$ Benjamin Seunes, ${ }^{1}$ Philippe Prior, ${ }^{2}$ and Christian Boucher ${ }^{1}$ \\ ${ }^{1}$ Laboratoire des Interactions Plantes Microorganismes INRA-CNRS, BP27, 31326 Castanet Tolosan Cedex, France; \\ ${ }^{2}$ Station de Pathologie végétale Domaine Saint-Maurice BP 9484143 Montfavet Cedex, France
}

Submitted 12 November 2003. Accepted 7 March 2004.

In Ralstonia solanacearum, we previously have reported on the characterization of popP1 and popP2 genes. These genes encode type III-dependent pathogenicity effectors related to the large family of AvrRxv/YopJ cysteine proteases that are shared among pathogens of plants and animals. In this study, we identify a third gene, named popP3, that is inactivated in the genome sequence of strain GMI1000 by insertion of a copy of the insertion sequence ISRso13. The three popP genes are localized on two large chromosomal pathogenicity islands, with popP1 and popP2 being present on the same island. Phylogenic analysis demonstrated that the PopP2 and PopP3 proteins are clearly distinct from other effectors of this family previously characterized in plant and animal pathogens. Analysis of the distribution and allelic variations of the three genes in 30 strains representative of the biodiversity of $R$. solanacearum established that popP genes are distributed widely among strains from two of the three phyla previously defined on the basis of the structure of the core genome. Sequencing of the popP genes from the different strains revealed limited allelic variations at the three loci but did not show evidence of recombination between the popP genes. Limited allelic variation together with occurrence of insertion sequences within or in the close vicinity of popP genes and the presence of gene duplications in these pathogenicity islands suggest that genomic rearrangements might be a major evolutionary driving force controlling evolution of the genes encoded in these regions. The implications of these observations in terms of bacterial evolution, gene acquisition, and horizontal gene transfers are discussed.

Sequencing and the subsequent comparison of complete bacterial genomes has dramatically changed our vision concerning the notion of bacterial species and of the processes that govern evolution of these organisms. A new light has been thrown on the major role played by horizontal gene transfers (Gogarten et al. 2002; Hacker et al. 2003; Jain et al. 2002; Ochman et al. 2000). For bacteria pathogenic to humans, comparison of their genomes to closely related nonpathogenic strains revealed that these organisms share a large number of

Corresponding author: C. Boucher; Telephone: (33) 5612854 16; Fax: (33) 561285061 ; E-mail: boucher@toulouse.inra.fr

* The $\boldsymbol{e}$-Xtra logo stands for "electronic extra" and indicates the HTML abstract available on-line contains two supplemental tables not included in the print edition. common genes, referred to as the "core genome", that includes genes encoding basic housekeeping functions. Apart from the core genome, which can be considered as the skeleton for each particular species, different strains from the same species often differ from each other by a large number of genes that are present in one strain but absent in another (Buchrieser et al. 2003; Perna et al. 2001). These genes often are organized in clusters and often have a biased base composition compared with the core genome. In addition, they often encode functions that improve the fitness of the bacteria under particular environmental conditions, including the ability to invade the tissues of a living organism in the case of pathogenic bacteria (Jain et al. 2003). Moreover, these frequently are associated with mobile genetic elements such as prophages and insertion sequences (IS), suggesting that they were acquired from various sources through horizontal gene transfers. These observations led Hacker and associates (2003) to reinforce the concept of a pathogenicity island and to stress the crucial role that these elements may play in bacterial evolution (Hacker and Kaper 2000).

Very limited data is available concerning the role such gene islands could play in the evolution of pathogenicity and host specificity toward plants. The most documented set of data comes from the pathogenicity island of Pseudomonas syringae and is centered on hrp genes that encode a type-III protein secretion system (Alfano et al. 2000; Charity et al. 2003; Hutcheson 1999).

Sequencing of the genomes of the plant-pathogenic bacteria Ralstonia solanacearum (Salanoubat et al. 2002), Xanthomonas campestris, X. axonopodis (da Silva et al. 2002), and $P$. syringae (Buell et al. 2003) has established the presence of genomic islands with a $\mathrm{G}+\mathrm{C}$ biased composition in the genome of each of these organisms. Candidate or established pathogenicity genes are present in several of these genomic islands. In $R$. solanacearum, these regions, named alternative codon usage regions (ACURs), encompass $7 \%$ of the genome and are distributed over the two large replicons that constitute the bacterial genome. In contrast to the situation reported for P. syringae (Alfano et al. 2000; Hutcheson, 1999), $R$. solanacearum hrp gene cluster cannot be distinguished from the core genome on the basis of DNA composition or on the basis of associated mobile genetic elements. A recent study has established that, in this bacterium, hrp genes have co-evolved with ribosomal genes (Gophna et al. 2003) and, therefore, are part of the core genome. On the other hand, a significant proportion of candidate effector genes identified in $R$. solanacearum are located within ACURs (Cunnac et al. in press; Salanoubat et al. 2002). This, together with the abil- 
ity of this bacterium to be naturally competent for DNA transformation (Bertolla et al. 1997), strongly suggests that several type-III effector genes might have been acquired relatively recently through horizontal gene transfers and that this could play a significant role in adaptation of this versatile plant pathogen to a wide range of potential hosts.

$R$. solanacearum is a complex species, grouping strains with differences in virulence, host range, mode of transmission, and metabolic properties. Based on these differences, several classification systems have been proposed. One is based on the host range of strains and originally distinguished three "races" (Buddenhagen et al. 1962). It later was extended to five races to include strains pathogenic on ginger (Pegg and Moffett 1971) and mulberry (He et al. 1983). An independent classification into six "biovars" is based on the ability of strains to metabolize disaccharides and hexosealcohols (Hayward et al. 1964, 1991, 1994). A new classification scheme, based on analysis of restriction fragment length polymorphisms (RFLP) at the hrp locus and additional loci from the core genome (Cook et al. 1989; Cook and Sequeira 1994), revealed the existence of two divisions corresponding to two evolutionary phyla. Division I, also named "Asiaticum", comprises strains mainly isolated from Asia and Australia, whereas strains from division II, also known as "Americanum", mainly originate from South and Central America.

In addition, within each main division, this classification allows the identification of a subset of strains having a common RFLP patterns at different loci which, therefore, are referred to multilocus genotype or MLG groups. This grouping actually associates strains that share a common core genome structure (Cook and Sequeira 1994; M. Fegan and P. Prior, personal communication). The genetic classification thus defined correlates nicely with the biovar classification because strains from division Asiaticum match biovars 3, 4, and 5 and strains from division Americanum match biovars 1, 2, and N2. The diversification of $R$. solanacearum into two major phyla later was confirmed using additional molecular criteria addressing various elements of the core genome including i) polymerase chain reaction (PCR)-RFLP analysis of pglA polygalacturonase and hrp genes (Gillings et al. 1993; Poussier et al. 1999), ii) comparisons of rRNA sequences (Li et al. 1993; Poussier et al. 2002b; Seal et al. 1993; Taghavi et al. 1996), iii) amplified fragment length polymorphism (AFLP) analysis on genomic DNA (Poussier et al. 2000b), and iv) comparison of a partial nucleotide sequence of the $h r p B$ and eglA endoglucanase genes (Poussier et al. 2000a). Some of these studies allowed identification of a third phylum corresponding to strains originating from Africa; however, the position of this phylum relative to the two other phyla is still unclear (Poussier et al. 1999, 2000a, 2000b).

Although race 3 classifies as biovar 2, no other correlation can be drawn between host range (races) and the other classifications based on analysis of genes from the core genome. This, together with the fact that a large proportion of effector genes are present in ACURs, suggests that, in $R$. solanacearum, host range might be a biological trait under fast evolutionary adaptation depending on high-frequency horizontal gene acquisitions and deletions. In order to test this hypothesis, we investigated the distribution and allelic variations of a family of three effector proteins among a collection of $R$. solanacearum strains representative of the biodiversity of this species. The three genes chosen for this study encode members of a family of potential cysteine proteases referred to as AvrRxv/YopJ effectors. Members of this family are widely conserved among a type-III secretion system harboring gramnegative pathogens of plants and animals (Orth 2002).

\section{RESULTS}

$R$. solanacearum encodes at least three evolutionarily distant genes for AvrRxv/YopJ-related effectors.

Three structural genes for members of the AvrRxv/YopJ protein family are present in $R$. solanacearum strain GMI1000. Two of them have been identified previously as popPl and popP 2 and encode avirulence proteins recognized by petunia (Lavie et al. 2002) and Arabidopsis thaliana (Deslandes et al. 2003), respectively. In addition, it was shown that the PopP1 protein modulates aggressiveness of the bacterium toward tomato (Lavie et al. 2002). The third gene, named popP3, is inactivated in strain GMI1000 by a copy of the insertion sequence ISRso13, and initially was described as RS02458 and RS02460 in the original annotation of the genome sequence. Analysis of the seven ISRso13 sequences that are present in the genome of strain GMI1000 shows that insertion of this IS generates an 11-bp duplication at the insertion site. Therefore, it was possible to reconstitute the DNA sequence of the native popP3 gene before insertion of the IS occurred. The corresponding functional gene codes for a protein of 386 amino acid (aa) residues, whereas popP1 and popP2 encode 368 and 483 aa proteins, respectively. For convenience, these three genes will be further referred to collectively as "popP genes" and the corresponding proteins as "PopP proteins". When the three proteins are aligned with the pairwise alignment program of the Bioedit software package using the PAM250 similarity matrix, global identity of $17 \%$ was found between PopP2 and PopP3, 18\% between PopP1 and PopP2, and 20\% between PopP1 and PopP3. PopP1, PopP2, and PopP3 share $42 \%$ global similarity. The highest homology was found in the central region of the proteins which contain the catalytic site of C55 cysteine proteases that is conserved among all members of the AvrRxv/YopJ effector family. In contrast, the three proteins are highly divergent at their N-terminal ends. PopP2 harbors a long N-terminal extension that includes a nuclear localization signal at position 33-53 that promotes addressing of the protein into plant cell nucleus after translocation into the plant cell (Deslandes et al. 2003). On the other hand, PopP3 harbors an N-terminal potential myristoylation site as defined by Johnson and associates (1994) located at position 2-7. Neither of these two signals are predicted in PopP1.

When a multiple alignment of the PopP proteins with other members of the AvrRxv/YopJ family of effectors was generated, the resulting neighbor-joining tree clearly established that PopP1 clusters with one of the two groups of the other members of the family originating from plant-pathogenic and symbiotic bacteria. PopP2 and Pop3 are clearly distinct from these two groups and from the cluster of proteins identified in animal pathogens as well as from the HopPmaD protein from P. syringae pv. maculicola (Fig. 1).

\section{PopP genes are encoded}

within two distinct pathogenicity islands.

With a respective $\mathrm{G}+\mathrm{C}$ base composition of 55,60 , and $62 \%$ that is markedly different from the average value of $67 \%$ characteristic for the entire genome of strain GMI1000, popP1, popP2, and popP3 are located within ACURs. In addition, popP 1 and popP 2 are part of a $79-\mathrm{kb}$ chromosomal pathogenicity island extending between the RSc0821 gene and the tmRNA gene ssrA. In addition to harboring several ACURs, this region is characterized by the presence of several genes originating from phages, two insertion sequences (ISRso9 and ISRso14), and one partial copy of ISRso1. It also carries several potential pathogenicity genes, such as the genes for the hemaglutinin-related protein RSc0887, and the RSc0824 and $\mathrm{RSc} 0895$ proteins that share a high homology in their $\mathrm{N}$-ter- 
minus with the N-terminus of PthG, a protein controlling both aggressiveness and host specificity in the plant pathogen Erwinia herbicola pv. gypsophylae (Ezra et al. 2000). This pathogenicity island also harbors several stretches of DNA that are duplicated elsewhere in the genome.

Similarly, popP3 is part of an 83-kb genomic island located near the origin of replication of the chromosome. This island is bordered on one side by the cysCl gene that codes for an adenylylsulfate kinase and by an Ala-tRNA (RS02400) on the other side. This region is characterized by the presence of several long ACURs and two copies of both ISRso1 and ISRso13. Furthermore, several phage genes and numerous structural genes for proteins with unknown functions are present in this island. This region also is particularly rich in DNA stretches that are duplicated elsewhere in the genome. In particular, two duplications are shared between the popPl-popP2 and the popP3 pathogenicity islands, with rs16 occurring in direct orientation and rs 22 in reverse orientation.

\section{popP genes are present}

in most Asiaticum and African isolates but are generally absent from Americanum isolates.

As a first step toward the analysis of the potential contribution of horizontal gene transfer to strain variability in $R$. solanacearum, we used a collection of 30 strains representative of the different races, biovars, and genetic groups previously described to monitor the distribution of popP genes in this species. The positioning of each of these strains according to the Americanum, Asiaticum, or African divisions is shown in Table 1 and was confirmed using multiplex PCR as defined by $\mathrm{M}$. Fegan and P. Prior (personal communication). In the case of race 2 strains originally described as pathogenic on Musa spp., further genomic characterization was performed to differentiate them according to the MLG classification (Cook and Sequeira 1994; M. Fegan and P. Prior, personal communication).
The distribution of popP genes among this strain collection was first analyzed by Southern hybridization of total genomic DNA with various probes corresponding to PCR amplicons of popPl and popP2 genes obtained from strain GMI1000 and to the popP3 gene amplified from strain GMI8084. The nucleotide sequences of these three probes are highly divergent so that no cross-hybridization occurred under the experimental conditions used (data not shown). Clear hybridization signals were detected with at least one of the probes in all but one (Rd15) of the strains from the Asiaticum and African divisions (Table 1). The majority of these strains gave a positive signal with two of the three probes. Three other strains only hybridized with popPl and two strains (GMI8160 and GMI1000) gave a positive signal for the three genes. Another strain (JT685) gave a positive signal only with popP1. All three genes appear to be almost equally represented among the Asiaticum strains tested. Positive hybridization signals with the popPl probe also were obtained with the three African strains included in this study. These strains did not hybridize with the popP2 probe and only one of them hybridized with the $p o p P 3$ probe.

Conversely, with the exception of strains from MLG25, all of the Americanum strains tested were consistently negative when probed with the three popP genes.

A gene family with limited allelic variability at each locus.

To confirm the positive signals observed in Southern hybridization and to establish the nucleotide sequences at each popP locus, PCR experiments were conducted to amplify the genes, or parts thereof, from strains that were positive in Southern hybridizations. This allowed us to determine the sequence for the full-length PopP1 and PopP2 coding genes for strains from the Asiaticum and the African divisions. For popP3 genes, sequences covering $1,137 \mathrm{bp}$ of the $3^{\prime}$ end of the 1,161-bp popP3 gene were obtained. In the case of strains

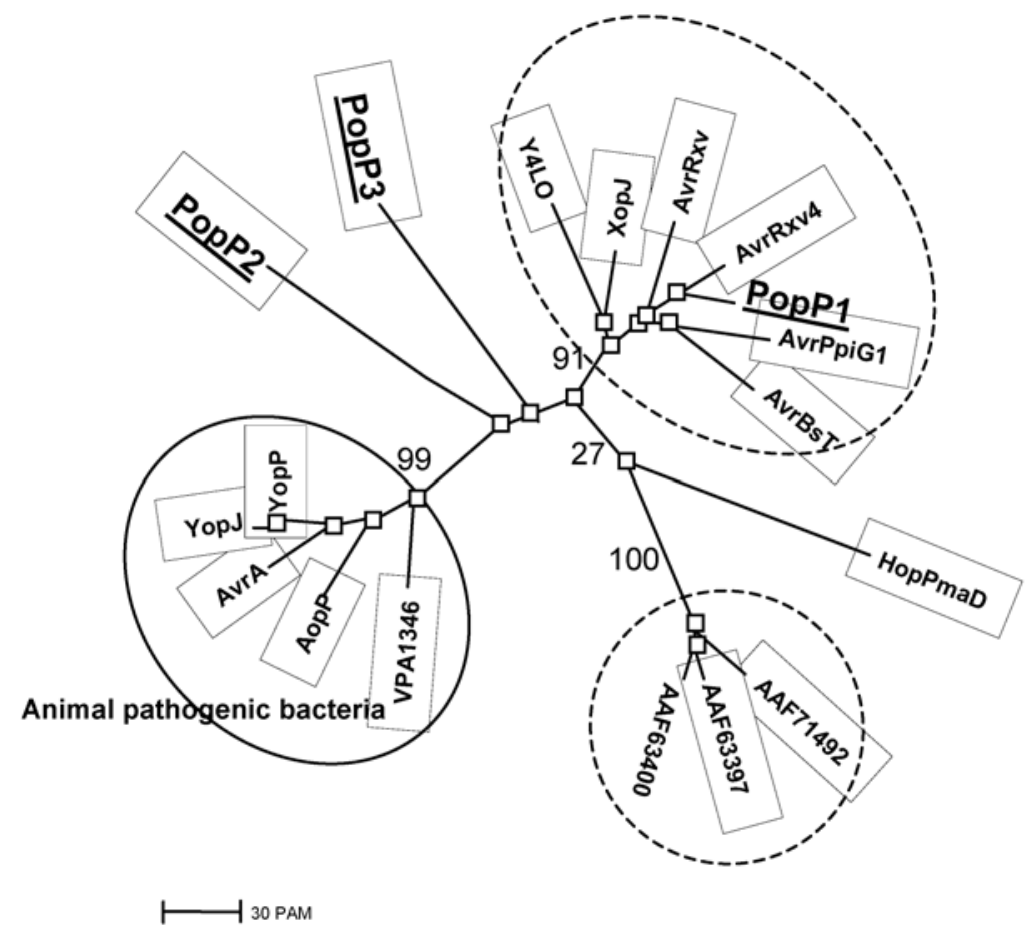

Fig. 1. Phylogenic tree of members showing the relationship between members of AvrRxv/YopJ family of type III-dependent pathogenicity effectors. Accession numbers for the proteins are: Yersinia pseudotuberculosis YopJ, P31498; Y. enterocolitica YopP, NP-052382; Salmonella enterica AvrA, AAB83970; Xanthomonas axonopodis (campestris) AvrRxv, Q08678; AvrBsT, AAD39255; XopJ, AAK72486; AvrXv4, AAG39033; Pseudomonas syringae AvrPpiG1, CAC16700; HopPmaD, AAL84243; AAF71492, AAF71492; Erwinia amylovora AAF63400, AAF63400; AAF63397, AAF63397; Aeromonas salmonicida sp. salmonicida AopP, NP_710166; Vibrio parahaemolyticus VPA1346, NP_800856; Rhizobium sp. Y4LO, NP-443964. Relevant bootstrap values are shown on the graph. 
from the subgroup MLG25, only partial popP1 gene fragments of $771 \mathrm{bp}$ covering the $3^{\prime}$ end of the 1,107-bp PopP1 coding sequence could be amplified and sequenced. The results from PCR amplifications confirmed the presence of popP genes in all the strains that gave a positive hybridization signal in Southern hybridization, with the exception of popP2 amplicons from the MLG25 strains (discussed below). All these sequences are available in the GenBank database under accession numbers AJ628876 to AJ628895.

In several cases, the sequences thus generated revealed the presence of an insertion sequence within or flanking the corresponding gene (Table 1). Where this occurred, the sequence of the native gene was established by removal of the IS sequence and of its flanking base pair duplication generated by the insertion process. The sequences obtained for each locus were aligned using Clustal X software and the corresponding neighbor-joining trees were constructed.

The neighbor-joining tree corresponding to the alignment of $771 \mathrm{bp}$ covering the last codons of the popP1 loci is shown in Figure 2A. It establishes that, with a bootstrap value of over 70 , the popP1 genes can be classified in three major allelic groups. Group 1A includes three Asiaticum iso- lates, group 1B includes both African and Asiaticum isolates, and group $1 \mathrm{C}$ is characteristic of the MLG25 subgroup of Americanum isolates. The six popPl partial sequences from group $1 \mathrm{C}$ were completely identical even though the corresponding strains originated from different geographical areas, including French West Indies and South and Central America. Comparison of the full-length popPl genes from group 1A were found to encode identical proteins, although one single silent base change was detected in one strain. Genes of the 1B group, however, are more variable and can be distinguished from the group 1A alleles on the basis of 54 conserved base changes resulting in 10 conserved amino acid changes at the protein level (Table 2). The PopP1 proteins from group 1A share $95 \%$ identity with the PopP1 proteins from group $1 \mathrm{~B}$. The partial C-terminal sequence of proteins from group 1C shares 97 to $98 \%$ amino acid identity with the corresponding regions of proteins from both group $1 \mathrm{~A}$ and 1B. Three of the characterized popPl genes, one from group $1 \mathrm{~A}$ and two from group $1 \mathrm{~B}$, are disrupted by an IS. The IS differs from strain to strain and is inserted at different locations within the gene, indicating that these insertions correspond to recent evolutionary events (Fig. 3).

Table 1. Characteristics of the Ralstonia solanacearum strains used in this study and summary of the distribution of the allelic forms of popP genes present in these strains

\begin{tabular}{|c|c|c|c|c|c|c|c|c|c|}
\hline \multirow[b]{2}{*}{ Strains $^{\mathbf{b}}$} & \multirow[b]{2}{*}{ Other designation $^{b}$} & \multirow[b]{2}{*}{ Geographical origin } & \multirow[b]{2}{*}{ Isolated from } & \multirow[b]{2}{*}{$\operatorname{Ref}^{c}$} & \multirow[b]{2}{*}{$B v^{d}$} & \multirow[b]{2}{*}{ Div, MLG $^{\mathbf{e}}$} & \multicolumn{3}{|c|}{ Presence of popP alleles ${ }^{a}$} \\
\hline & & & & & & & popP1 & popP2 & popP3 \\
\hline UW20 & & Venezuela & Banana & 1 & 1 & Am/MLG28 & - & - & - \\
\hline UW9 & GMI8132, JT644 & Costa Rica & Heliconia sp. & 2 & 1 & Am/MLG24 & - & - & - \\
\hline UW135 & $\ldots$ & Honduras & Banana & 1 & 1 & Am/MLG24 & - & - & - \\
\hline UW167 & $\ldots$ & Costa Rica & Banana & 1 & 1 & Am/MLG24 & - & - & - \\
\hline UW11 & $\ldots$ & Costa Rica & Heliconia sp. & 3 & 1 & Am/MLG24 & - & - & - \\
\hline MOLK2 & GMI8238 & Indonesia & Banana & 3 & 1 & Am/MLG24 & - & - & - \\
\hline UW30 & GMI8124 & Trinidad & Tomato & 2 & 1 & $\mathrm{Am}$ & - & - & - \\
\hline UW26 & GMI8122 & United States & Tomato & 2 & 1 & $\mathrm{Am}$ & - & - & - \\
\hline UW25 & K60 & United States & Tomato & 1 & 1 & $\mathrm{Am}$ & - & - & - \\
\hline NCPPB3987 & GMI8227, JT677 & Brazil & Potato & 2 & N2 & Am & - & - & - \\
\hline 1609 & $\ldots$ & Nederlands & Potato & 6 & 2 & $\mathrm{Am}$ & - & - & - \\
\hline UW23 & GMI8139 & Israel & Potato & 1 & 2 & $\mathrm{Am}$ & - & - & - \\
\hline UW127 & GMI8135 & Perou & Plantain & 1 & 1 & Am/MLG25 & $1 \mathrm{C}$ & + & $3 C^{*}$ \\
\hline UW129 & $\ldots$ & Perou & Plantain & 3 & 1 & Am/MLG25 & $1 \mathrm{C}$ & + & $3 C^{*}$ \\
\hline UW163 & GMI8235 & Perou & Plantain & 3 & 1 & Am/MLG25 & $1 \mathrm{C}$ & + & $3 C^{*}$ \\
\hline CFBP1419 & JS847, UW156 & Costa Rica & Musa sp. & 3 & 1 & Am/MLG25 & $1 \mathrm{C}$ & + & $3 \mathrm{C}$ \\
\hline Ant307 & $\ldots$ & French West Indies & Anthurium & 3 & 1 & Am/MLG25 & $1 \mathrm{C}$ & + & - \\
\hline Ant1121 & $\ldots$ & French West Indies & Anthurium & 3 & 1 & Am/MLG25 & $1 \mathrm{C}$ & + & - \\
\hline GMI1000 & $\ldots$ & Guyana & Tomato & 4 & 3 & As & $1 \mathrm{~A}$ & $2 \mathrm{~A}$ & $\begin{array}{l}3 \mathrm{~A}:: \text { ISRso1 } \\
3\end{array}$ \\
\hline GMI8160 & & French West Indies & Eggplant & 7 & 4 & As & $1 \mathrm{~A}$ & $2 \mathrm{~A}$ & $3 \mathrm{~A}^{*}$ \\
\hline JT685 & GMI8228 & China & Mulberry & 2 & 5 & As & 1A::IS1420 & - & - \\
\hline GMI8081 & $\ldots$ & Australia & Tomato & 7 & 3 & As & - & $2 \mathrm{~A}$ & $3 \mathrm{~A}^{*}$ \\
\hline GMI8085 & $\ldots$ & Australia & Xanthium pungens & 7 & 3 & As & - & $2 \mathrm{~A}$ & $3 \mathrm{~A}^{*}$ \\
\hline GMI8084 & $\ldots$ & Australia & Tomato & 7 & 3 & As & - & $2 \mathrm{~A}$ & $3 \mathrm{~A}^{*}$ \\
\hline UW74 & JS841, GMI8230 & Sri Lanka & Potato & 2 & 4 & As & 1B & $2 \mathrm{~B}^{*}$ & - \\
\hline GMI8093 & 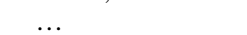 & Australia & Ginger & 7 & 4 & As & 1B::IS1021 & $2 \mathrm{~B}$ & - \\
\hline NCPPB332 & JS949 & Zimbabwe & Potato & 2 & 1 & Af & 1B & - & 3B \\
\hline CFBP3059 & JS904 & Burkina Faso & Eggplant & 2 & 1 & Af & $1 \mathrm{~B}$ & - & - \\
\hline JT525 & GMI8237 & Reunion Island & Pelargonium & & & & & & \\
\hline $\mathrm{Rd} 15$ & $\ldots$ & Taiwan & $\begin{array}{l}\text { asperum } \\
\text { Radish }\end{array}$ & $\begin{array}{l}2 \\
5\end{array}$ & $\begin{array}{l}1 \\
3\end{array}$ & $\begin{array}{l}\text { Af } \\
\text { As }\end{array}$ & $\begin{array}{l}\text { 1B::IS } \\
-\end{array}$ & - & - \\
\hline
\end{tabular}

a рорP: presence of the genes $\operatorname{pop} P 1$, рорP2, or popP3 in the strains; - indicates that no signal was obtained in Southern hybridization with the corresponding рорP probe; + indicates that a signal was detected in Southern hybridization with the corresponding popP probe but no amplicon of the gene or part of it could be produced. 1A, 1B, 1C, 2A, 2B, 3A, 3B, and 3C correspond respectively to the different allelic groups of popP1, popP2, and рорP3 genes defined on the basis of phylogenetic analysis that were found in the strains. The presence of an insertion sequence in certain gene is indicated by ::IS; * indicates strains where multiple copies of the corresponding gene are detected based on Southern hybridization.

${ }^{\mathrm{b}}$ Strain designation: CFBP, Collection Française de Bactéries Phytopathogènes, INRA Angers, France; NCPPB, National Collection of Plant Pathogenic Bacteria, Harpenden, U.K.; UW, D. Cook and L. Sequeira, Department of Plant Pathology, University of Wisconsin-Madison, U.S.A.; GMI, CNRS-INRA, Auzeville, Castanet Tolosan Cedex, France; JS and JT, laboratoire de phytopathologie, CIRAD-FLHOR, Saint-Pierre, La Réunion, France.

${ }^{\mathrm{c}}$ References: 1 , Cook et al. $1989 ; 2$, Poussier et al. 2000b; 3, P. Prior and M. Fegan, personal communication; 4, Salanoubat et al. $2002 ; 5$, Deslandes et al. 1998; 6, Van Elsas et al. 2000 ; 7, this study.

${ }^{\mathrm{d}}$ Biovars.

e Division (Div): As, Asiaticum; Am, Americanum; and Af, African as defined by Cook and associates (1989) and Poussier and associates (1999). Multilocus genotype (MLGs) as defined by Cook and Sequeira (1994). 
A similar analysis was performed on the full-length popP2 genes (Fig. 2B) allowing the definition of two clearly distinct groups of alleles referred to as $2 \mathrm{~A}$ and $2 \mathrm{~B}$.

These two groups can be distinguished on the basis of 13 specific base substitutions resulting in six amino acid changes in the proteins (Table 2). Proteins from group 2A are identical and share $98 \%$ of identity with group $2 \mathrm{~B}$ proteins. The two proteins from group $2 \mathrm{~B}$ differ from each other by one single amino acid change, Q81H.

No amplicon could be obtained for popP 2 in strains from MLG25. However, Southern hybridizations performed under high-stringency conditions reproducibly gave a clear hybridization pattern on these strains. The pattern observed for the six MLG25 strains is not enlightened by a popP1 or a popP3 probe (data not shown) and clearly is distinct from the patterns obtained with the popP2 probe on the other strains (Fig. 4). Altogether, this is a good indication that a popP2 gene might

Table 2: Positions and identity of discriminative amino acids between alleles $1 \mathrm{~A}$ and $1 \mathrm{~B}$ of the PopP1 proteins and between alleles $2 \mathrm{~A}$ and $2 \mathrm{~B}$ of the PopP2 proteins

\begin{tabular}{|c|c|c|c|c|}
\hline \multirow[b]{3}{*}{ Positions } & \multicolumn{4}{|c|}{ Amino acids at allelic forms } \\
\hline & \multicolumn{2}{|c|}{ PopP1 } & \multicolumn{2}{|c|}{ PopP2 } \\
\hline & $\mathbf{1 A}$ & $1 B$ & $2 \mathbf{A}$ & $2 B$ \\
\hline 71 & $\mathrm{M}$ & A & $\ldots$ & $\ldots$ \\
\hline 90 & $\mathrm{~S}$ & A & $\ldots$ & $\ldots$ \\
\hline 97 & $\mathrm{H}$ & $\mathrm{S}$ & $\ldots$ & $\ldots$ \\
\hline 132 & $\mathrm{Q}$ & $\mathrm{E}$ & $\ldots$ & $\ldots$ \\
\hline 156 & $\mathrm{G}$ & A & $\ldots$ & $\ldots$ \\
\hline 239 & A & V & $\ldots$ & $\ldots$ \\
\hline 280 & $\mathrm{H}$ & $\mathrm{R}$ & $\ldots$ & $\ldots$ \\
\hline 282 & $\mathrm{Y}$ & $\mathrm{Q}$ & $\ldots$ & $\ldots$ \\
\hline 285 & $\mathrm{H}$ & $\mathrm{Y}$ & $\ldots$ & $\ldots$ \\
\hline 326 & $\mathrm{R}$ & $\mathrm{S}$ & $\ldots$ & $\ldots$ \\
\hline 13 & $\ldots$ & $\ldots$ & $\mathrm{S}$ & $\mathrm{N}$ \\
\hline 115 & $\ldots$ & $\ldots$ & $\mathrm{L}$ & $\mathrm{P}$ \\
\hline 146 & $\ldots$ & $\ldots$ & $\mathrm{R}$ & $\mathrm{H}$ \\
\hline 156 & $\ldots$ & $\ldots$ & $\mathrm{G}$ & D \\
\hline 288 & $\ldots$ & $\ldots$ & $\mathrm{S}$ & $\mathrm{N}$ \\
\hline 396 & $\ldots$ & $\ldots$ & $\mathrm{G}$ & $\mathrm{E}$ \\
\hline
\end{tabular}

be present in MLG25 strains and that these genes might form a distinct allelic group referred to as $2 \mathrm{C}$.

Concerning PopP3, the neighbor-joining tree obtained after alignment of the $1,137 \mathrm{bp}$ located at the $3^{\prime}$ end of the popP3 open reading frame identifies three groups of alleles $(3 \mathrm{~A}, 3 \mathrm{~B}$, and 3C) with a bootstrap value of above $99 \%$ (Fig. 2C). Strains from group $3 \mathrm{~A}$ harbor popP3 genes whose sequences are identical to the sequence of the allele found in strain GMI1000, except that these genes are not interrupted by insertion of ISRso13. Group 3B is composed of a single gene originating from an African isolate. The corresponding protein sequences (379 aa) share 88 and $92 \%$ identity with the PopP3 sequences from groups $3 \mathrm{~A}$ and $3 \mathrm{C}$, respectively.

Group 3C corresponds to four identical popP3 genes present in strains from the MLG25 subdivision of the Americanum phylum. The corresponding protein sequences share $88 \%$ identity with the protein sequences from group $3 \mathrm{~A}$.

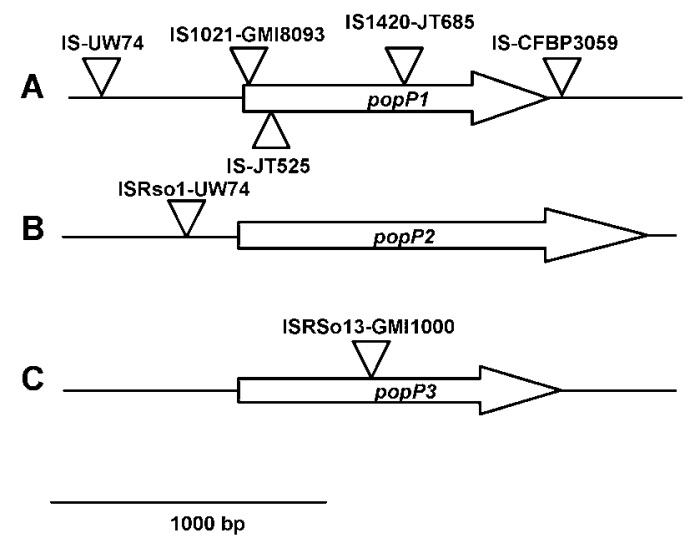

Fig. 3. Schematic representation of the locations of the insertions sequences present within or in the vicinity of $\mathbf{A}$, popPl, $\mathbf{B}$, popP2, and $\mathbf{C}$, popP 3 genes in the Ralstonia solanacearum strains studied. The positions of insertion sequence (IS) insertions are indicated by an arrow; the name of the corresponding IS and the strain in which the insertion was present are indicated next to the arrow.

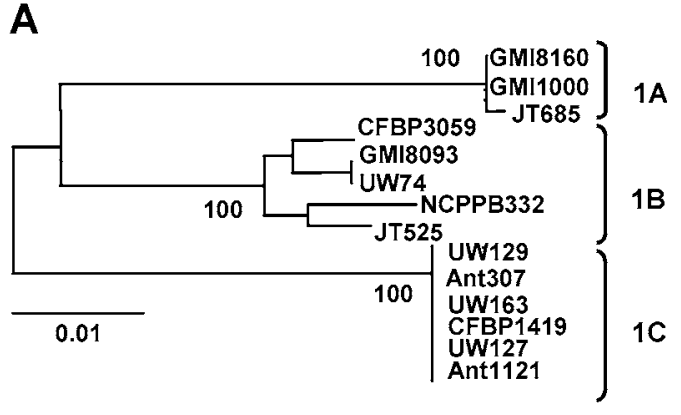

popP1
B

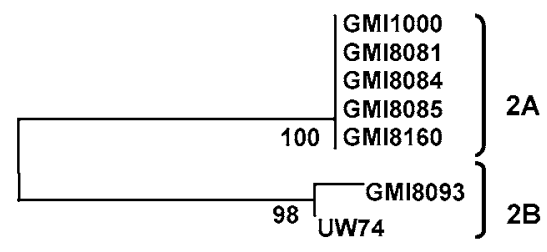

0.001

\section{popP2}

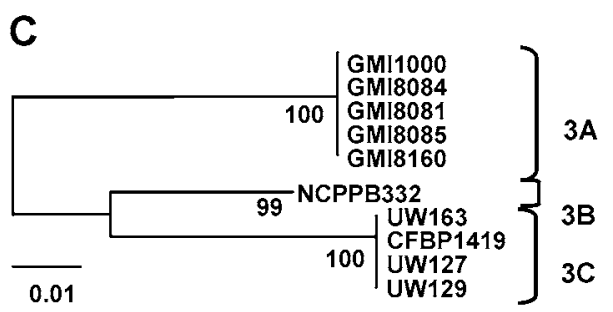

popP3

Fig. 2. Neighbor-joining tree established upon alignments of the nucleotide sequences of A, partial popP1, B, full-length popP2, and C, partial-length popP3 genes showing the grouping in allelic forms. The numbers at the branch points correspond to the percentages of bootstrap replicates in which the clusters are found. 
Taken all together, these results confirm the presence of at least one popP gene in all but one of the strains from the Asiaticum division (Table 1). They also confirm that MLG25 strains form a specific group among Americanum strains because they are the only strains from this phylum to harbor popP genes. However, the popP alleles found in these strains are clearly distinct from the alleles identified in Asiaticum strains. In addition, our data show that, when more than one popP gene is present in a strain, no recombination is observed between the three loci because the same combination of alleles are always found (i.e., a popPl allele from group $1 \mathrm{~A}$ exclusively is found associated with a group $2 \mathrm{~A}$ allele of popP2 and with a group $3 \mathrm{~A}$ allele of popP3). The same is true for popP genes from allelic groups $\mathrm{B}$ and $\mathrm{C}$.

\section{Occurrence of popP gene duplications.}

In several cases, the banding patterns obtained in Southern blots of EcoRI-digested genomic DNA suggested that more than one copy of the gene was present in a single strain. For example, strain UW74, which carries a 2B allele of popP2, harbors four fragments that hybridize with the popP2 (Fig. 5A). Two of these fragments are shared with strain GMI8093, which carries a $2 \mathrm{~B}$ allele of popP2. This allele harbors two internal EcoRI restriction site generating three restriction fragments with only two that are large enough to be visualized after hybridization. Therefore, the two additional hybridizing restriction fragments that are detected in strain UW74 correspond to at least one additional copy of a popP2 gene. As far as the $3 \mathrm{C}$ alleles of popP3 are concerned, even though a single hybridizing band was found for the strain CFB1419, additional bands with variable hybridizing intensity were detected in strains UW127, UW163 (Fig. 5B), and UW129 (data not

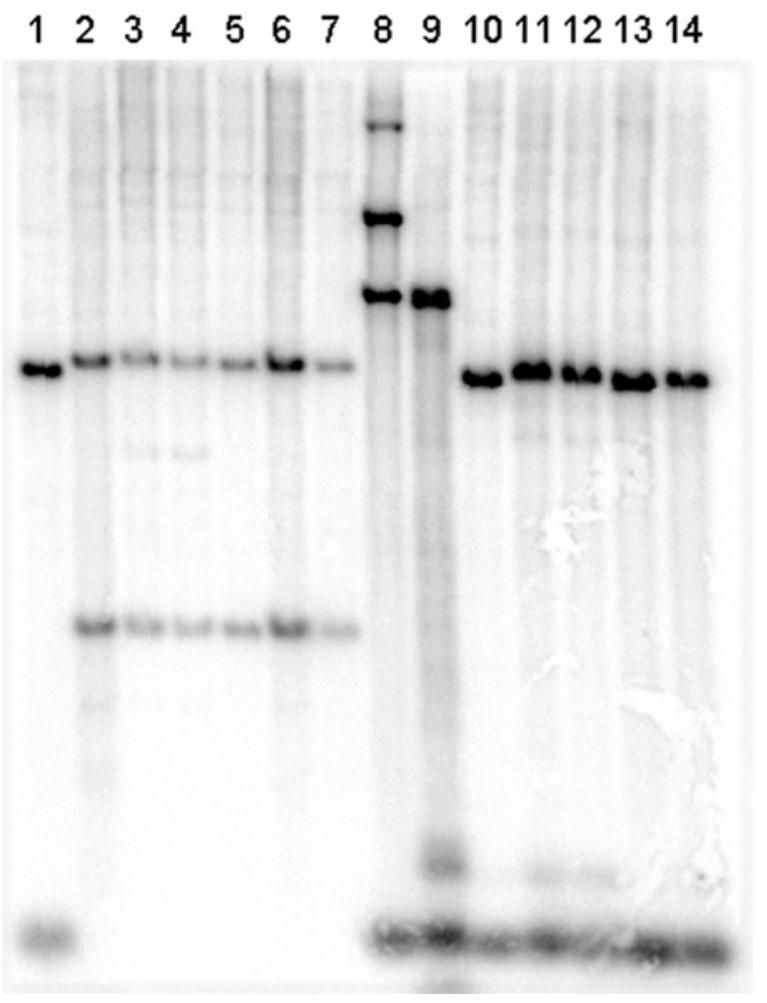

Fig. 4. Hybridization patterns of a popP2 probe against EcoRI digests of genomic DNA from selected positive strains of Ralstonia solanacearum belonging to the phyla Americanum and Asiaticum. Individual strains are: Lanes 1 and 10, GMI1000; lane 2, UW163; lane 3, Ant1121; lane 4, Ant307; lane 5, CFBP1419; lane 6, UW129; lane 7, UW127; lane 8, UW74; lane 9, GMI8093; lane 11, GMI8160; lane 12, GMI8085; lane 13, GMI8084; and lane 14, GMI8081. shown). No EcoRI site was present in the sequence of the corresponding $3 \mathrm{C}$ allele of popP3 amplicons; this demonstrates the presence of multiple copies of popP3-related genes in strains UW127, UW163, and UW129. The same reasoning was applied for the popP3 genes that are present in two copies in the strains GMI8160, GMI8081, and GMI8085 (Fig. 5B) and GMI8084 (data not shown). This data is summarized in Table 1.

When thermal asymmetric interlaced (TAIL) PCR amplification was conducted on the upstream and downstream regions of popP in the corresponding strains, no difference was detected in the sequence generated at each locus. This established that the duplication covered a region of at least $170 \mathrm{bp}$ on each side of PopP coding sequence. However, the difference in the size of the restriction fragments of the hybridizing fragments strongly suggests that the different copies of the duplicated genes are located within different genetic environments. Alternatively, differences in hybridization intensities of these additional bands may be an indication that the different copies of popP gene within a strain might be too different to be amplified with a common set of primers.

\section{Allelic variations}

of popP1 and popP2 do not affect their avirulence function.

In strain GMI1000, the popP1 and popP2 genes behave as avirulence determinants on Petunia St 40 and A. thaliana ecotype Nd-1, respectively (Deslandes et al. 2003; Lavie et al. 2002). To test whether the allelic variations observed within these genes actually affected their avirulence function, the popP1 1B allele from strain UW74, the popP2 2B allele from strain GMI8093, and the popP2 2B allele from UW74 were tested individually for avirulence activity following introduction of pML1, pML2, and pML3 plasmids into strain Rd15 that is virulent on petunia St40 and A. thaliana Nd-1. The $1 \mathrm{~B}$ allele used in these experiments was chosen as being the most divergent from the popPl gene present in strain GMI1000. The 2B PopP2 proteins from strains UW74 and GMI8093 differ by six and seven amino acid changes, respectively, from

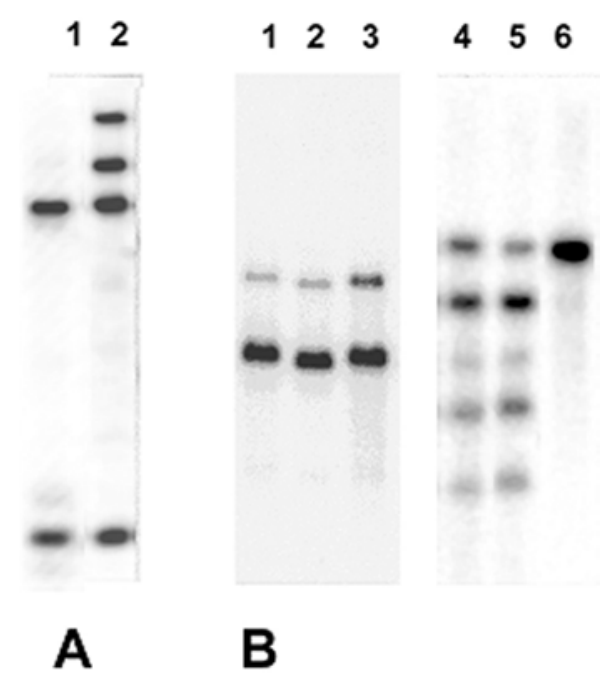

Fig. 5. Southern blot hybridization profiles of EcoRI-digested genomic DNA obtained with $\mathbf{A}$, a $p o p P 2$ probe and $\mathbf{B}$, a popP3 probe establishing the existence of рорP gene duplication in several strains of Ralstonia solanacearum. Hybridization probes used correspond to $\mathbf{A}$, popP 2 and $\mathbf{B}$, popP3. Genomic DNA originate from stains UW74 (A, lane 2), GMI8160 (B, lane 1), GMI8085 (B, lane 2), GMI8081 (B, lane 3), UW127 (B, lane 4), UW163 (B, lane 5), and CFBP1419 (B, lane 6). The hybridization profiles for strains GMI8093 (A, lane 1) and CFBP1419 (B, lane 6), which carry a single copy of the popP2 and popP3 genes, respectively, also are presented for comparison. 
GMI1000 PopP2. These tests were conducted as previously described using popP1 and popP2 genes from strain GMI1000 as controls (Deslandes et al. 2003; Lavie et al. 2002). In each case, no difference in avirulence activity was observed between the new allelic forms tested and the controls.

\section{DISCUSSION}

We previously characterized two genes in strain GMI1000 of $R$. solanacearum that encode proteins belonging to the AvrRxv/YopJ family of cysteine proteases that are secreted by type-III protein secretion machinery from bacterial pathogens (Deslandes et al. 2003; Lavie et al. 2002). In this study, we identified a third gene, called popP3, encoding a new member of this gene family. In addition, we show that occurrence of multiple members of this gene family is a common feature among $R$. solanacearum strains. This is a rather unusual situation among plant pathogens because the occurrence of several members of this gene family in a single strain has been reported only in $X$. campestris $p v$. vesicatoria (XcvT, race 175 3 ), in which the two closely related genes AvrRxv and AvrBsT are present (Ciesiolka et al. 1999).

In strain GMI1000, the structural genes for these PopP effectors are located at two distant regions of the chromosome harboring most of the features characteristic of pathogenicity islands. The popPl gene encodes a protein closely related to other members from this family that have been characterized in plant pathogens. The two others genes, popP2 and popP3, encode proteins that do not cluster with the other members of this family identified in either plant or mammal pathogens.

We also have established that the three popP genes are not evenly distributed among the three phyla identified in this species. They are found almost exclusively in strains that belong to the divisions Asiaticum and African and usually are absent from strains classified as Americanum. Considering the wide conservation of this gene family among bacteria pathogenic to plants and mammals (Orth 2002), it is surprising that such genes were absent from most Americanum strains. Therefore, this raises the question of whether other members of this gene family that remain to be identified are present in these strains. We know, however, that these genes are not essential for pathogenicity because a mutant of strain GMI1000 in which both popP1 and popP2 have been inactivated (in addition to popP3 that already is nonfunctional in this strain) retained the ability to cause disease on tomato and A. thaliana (data not shown).

Several features indicate that the three PopP proteins might not be functionally equivalent. It has been shown that PopP2 is addressed to the plant nucleus (Deslandes et al. 2003), whereas PopP1 and PopP3 are devoid of a predicted nuclear localization signal. A potential myristoylation site is present at the N-terminus of PopP3, suggesting that this protein could be addressed to the plant cell membrane as established for several Avr proteins from P. syringae (Nimchuk et al. 2000; Shan et al. 2000). In addition, PopP1 is predicted to remain in the cytoplasm after translocation into plant cell. This is a strong indication that the three effectors have different targets in the plant and, therefore, act differently in controlling plant-bacteria interactions.

We have shown that allelic variations of popP genes in $R$. solanacearum are rather limited and that they might have little effect on the functions of the corresponding proteins because the popP1 and popP2 variant alleles tested retained the avirulence function of the corresponding alleles in strain GMI1000. In contrast, great variability exists concerning the presence or absence of each individual gene and the number of copies of each popP gene present in a particular strain. Moreover, we found that, when present, expression of these genes frequently might be affected by the presence of IS elements within or in close vicinity to the coding sequence (Fig. 3). In addition to the popP3 gene that is disrupted in strain GMI1000, 3 of the 14 popP 1 genes sequenced were disrupted by an insertion sequence. Three IS also were found in popP flanking regions (one located $34 \mathrm{bp}$ after the popPl stop codon of strain CFBP3059, one at 500 bp before the popPl start codon of strain UW74, and one 180 bp upstream of the popP2 start codon of strain UW74). In addition, several DNA duplications have been identified within the popP1-popP2 and popP3 pathogenicity islands and several strains were identified in which individual popP genes have been duplicated. Taken together, these results indicate that genomic rearrangements may play a major role in the control of expression of the pathogenicity functions encoded at these loci.

In this study, a strong correlation between the distribution of popP genes and the phylogenic position of strains was established. Taking into account the large background of evidence that suggests that these genes have been acquired relatively recently through horizontal gene transfer, this result is rather unexpected. Contrary to what would be expected in case of independent horizontal acquisition of the popP1-popP2 and popP3 pathogenicity islands, recombination between popP1popP 2 and popP3 was never observed. Therefore, these observations favor a model in which a common ancestor to the African and Asiaticum phyla acquired popP genes through horizontal gene transfers. In addition, these genes would have been acquired more recently by a common ancestor of the subset of MLG25 strains from the phylum Americanum. According to such a model, one would predict that the long co-evolution of the popP genes with the core genome of Asiaticum and African strains should have resulted in adjustment of popP genes base composition to the average base composition of the genome. This clearly is different from what we observe.

An alternative scenario to explain the correlation between popP gene distribution and strain phylogeny would be that, in order to acquire or stably maintain the popP genes, the host strains require particular functions encoded only in the core genome of the Asiaticum and African strains. Such functions could include, for example, phage receptors, restriction or modification enzymes, other functions required for heterologous recombination of the incoming DNA, or alternatively, pathogenicity functions such as specific type-III effectors such as PopA, PopB, or PopW (Arlat et al. 1994; Guéneron et al. 2000; Salanoubat et al. 2002) that are encoded by genes indistinguishable from the core genome. However, again, the absence of recombination between the popP genes is in contradiction with this hypothesis.

In conclusion, the present study reveals that the mechanisms governing ACUR acquisition by $R$. solanacearum might be much more complex than we originally thought. Further work, based on the analysis of the distribution of a large number of effectors from ACUR, will be needed in order to understand the mechanisms which govern distribution and evolution of these genes in $R$. solanacearum and how these genes might be involved in adaptation of this versatile pathogen to its wide range of potential hosts.

\section{MATERIALS AND METHODS}

\section{Bacterial strains and growth conditions.}

Strain TG1 of Escherichia coli grown in Luria-Bertani medium (Sambrook et al. 1989) at $37^{\circ} \mathrm{C}$ was used for cloning experiments. $R$. solanacearum strains used in this study are listed in Table 1. All $R$. solanacearum strains were grown at $28^{\circ} \mathrm{C}$ in B medium (Boucher et al. 1985). When required, anti- 
biotics were used at the following concentrations: tetracycline at $10 \mathrm{mg} \mathrm{liter}{ }^{-1}$ and ampicillin at $50 \mathrm{mg} \mathrm{liter}^{-1}$.

\section{R. solanacearum electroporation.}

Plasmids were introduced into $R$. solanacearum strains by electroporation ( $2.5 \mathrm{kV}, 200 \mathrm{ohms}, 25 \mu \mathrm{Fd}, 0.2$-cm cuvette gap).

\section{Molecular biology techniques.}

Unless stated otherwise, standard methods were used (Ausubel et al. 1990). Genomic DNA was extracted from $R$. solanacearum strains as described by Arlat and associates (1992). PCR amplifications were done using the Expand Long Template PCR System (Roche Applied Science, Indianapolis, IN, U.S.A.).

For Southern analysis, approximately $3 \mu \mathrm{g}$ of EcoRIdigested genomic DNA was loaded per lane on an agarose gel. DNA was transferred to Hybond $\mathrm{N}+$ membranes (Amersham Biosciences, Piscataway, NJ, U.S.A.) and hybridizations were performed in $0.5 \mathrm{M}$ sodium phosphate, $\mathrm{pH} 7.2 ; 1 \mathrm{mM}$ EDTA, pH 8; 7\% sodium dodecyl sulfate (SDS); and salmon sperm DNA at $20 \mu \mathrm{g} / \mathrm{ml}$ at $65^{\circ} \mathrm{C}$. Membrane were washed at $65^{\circ} \mathrm{C}$ in $0.1 \times \mathrm{SSC}(1 \times \mathrm{SSC}$ is $0.15 \mathrm{M} \mathrm{NaCl}$ plus $0.015 \mathrm{M}$ sodium citrate) and $0.1 \%$ SDS buffer. The DNA probes were labeled with $\left[\alpha-\mathrm{P}^{32}\right] \mathrm{dCTP}$ using the kit Ready to Go (Amersham Biosciences). popP1 and popP2 probes were obtained by PCR amplifications of the popP1 and popP2 full gene sequences from strain GMI1000 using primers Fw4-P1/Rev1-P1 and Fw3-P2/Rev3-P2, respectively. The popP3 probe was obtained by PCR amplification of the coding sequence of popP 3 from strain GMI8084 using primers Fw1-P3 and Rev1-P3.

\section{DNA amplifications and sequencing.}

popP gene flanking sequences were isolated using TAILPCR performed according to the method described by Liu and Whittier (1995), except that the Expand Long Template PCR System (Roche) and corresponding elongation conditions were used for amplifications. Two different degenerate primers were tested for each amplification. The largest products obtained were approximately $2.5 \mathrm{~kb}$ long.

\section{popP gene amplification.}

Several methods were used to amplify popP genes prior to sequencing.

In most of the cases, primers located in the flanking regions of popP genes in strain GMI1000 genome were used successfully to amplify popP genes from other strains. When no product could be obtained in this way, primers internal to the popP coding sequences were tested. In such cases, the missing sequences corresponding to the $5^{\prime}$ and $3^{\prime}$ ends of the corresponding genes were determined on TAIL-PCR amplification products.

TAIL-PCR and PCR products were analyzed by gel electrophoresis and purification of amplicons was performed by passage through a $\mathrm{S} 400$ column (Amersham Biosciences) when a single amplicon was present in the reaction mixture. When several amplicons were present, individual amplicon products were purified by extraction of excised gel fragments containing each individual replicons. This extraction was performed using the Wizard SV gel and PCR clean-up system (Promega Bioscience, San Luis Obispo, CA, U.S.A.). The products thus obtained were used directly for sequencing.

\section{Plasmid constructions.}

pML2 and pML3 were constructed by cloning the popP2 genes from strains GMI8093 and UW74, respectively, between the restriction sites BamHI and HindIII of the pLAFR3 vector (Lindgren et al. 1986). popP2 genes were obtained by
PCR amplification of a 1,489-bp DNA fragment, extending from the ATG of the popP2 gene down to 23 bp downstream of the stop codon, using the primers Fw3-P2 and Rev3-P2 that introduced the BamHI and HindIII restriction sites at the end of the amplicon (Table 2). In the resulting constructs, gene expression was under the control of the plac promoter of pLAFR3.

To construct pML4, a fragment EcoRI-HindIII of $1.4 \mathrm{~kb}$, containing the popPl gene from strain GMI1000 together with $307 \mathrm{bp}$ of its $5^{\prime}$ flanking region and $35 \mathrm{bp}$ of its downstream sequence, was PCR amplified with the primers Fw2-P1/Rev2P1 that carry EcoRI and HindIII restriction sites, respectively, at their $5^{\prime}$ extremities. This fragment then was cloned between the EcoRI and HindIII restriction sites of pLAFR3.

pML1 is a pLAFR3 derivative in which a 1.4-kb EcoRIEcoRI fragment containing the popPl gene from strain UW74 was cloned into the EcoRI restriction site of the pLAFR3. In strain GMI1000, the $5^{\prime}$ extremities of primers Fw3-P1 and Rev4-P1 are located 48 bp upstream of the popP1 start codon and at $17 \mathrm{bp}$ downstream of the popPl stop codon, respectively. These primers allow the amplification of a $1.2-\mathrm{kb}$ DNA fragment. Using strain UW74 genomic DNA as template, the PCR amplification with Fw3-P1 and Rev4-P1 produced a DNA fragment of $2.5 \mathrm{~kb}$. The partial sequencing of this fragment showed that the entire popPl gene was contained between the Fw3-P1 primer and an EcoRI site present within the amplified DNA fragment. Hence, EcoRI digestion of the 2.5$\mathrm{kb}$ amplicon allowed isolation of a 1.4-kb DNA fragment that contained a full-length popPl gene. This fragment was cloned under the control of the plac promoter in pLAFR3.

\section{Plant tests.}

Pathogenicity assays on Arabidopsis (ecotypes Col-5 and Nd-1) and petunia plants were performed as previously described by Marenda and associates (1998) and Deslandes and associates (1998).

\section{Phylogenetic analysis.}

popP gene sequences were analyzed using the PHYLOWIN software package (Galtier et al. 1996). Sequences were aligned with the Clustal X 1.8 software (Thompson et al. 1997). Phylogenetic trees were constructed from the alignments by using the neighbor-joining method (Saitou and Nei 1987) with a correction of the evolutionary distances for multiple mutations with the Kimura formula. Bootstrapping was performed with 1,000 replicates. The resulting phylogenetic trees were visualized using the Treeview 1.6.6 software.

\section{ACKNOWLEDGMENTS}

We thank P. Boistard and S. Genin for valuable discussions and B. Hogg for editing of the manuscript.

\section{LITERATURE CITED}

Alfano, J. R., Charkowski, A. O., Deng, W. L., Badel, J. L., PetnickiOcwieja, T., van Dijk, K., and Collmer, A. 2000. The Pseudomonas syringae Hrp pathogenicity island has a tripartite mosaic structure composed of a cluster of type III secretion genes bounded by exchangeable effector and conserved effector loci that contribute to parasitic fitness and pathogenicity in plants. Proc. Natl. Acad. Sci. U.S.A. 97:4856-4861.

Arlat, M., Gough, C. L., Zischek, C., Barberis, P. A., Trigalet, A., and Boucher, C. A. 1992. Transcriptional organization and expression of the large hrp gene cluster of Pseudomonas solanacearum. Mol. PlantMicrobe Interact. 5:187-193.

Arlat, M., Van Gijsegem, F., Huet, J. C., Pernollet, J. C., and Boucher, C. A. 1994. PopA1, a protein which induces a hypersensitivity-like response on specific Petunia genotypes, is secreted via the Hrp pathway of Pseudomonas solanacearum. EMBO (Eur. Mol. Biol. Organ.) J. 13:543-553. 
Ausubel, F. M., Brent, R., Kingston, R. E., Moore, D. D., Seidman, J. G., Smith, J. A., and Struhl, K. 1990. Current Protocols in Molecular Microbiology. Green Publishing Associates and Wiley Interscience, New York.

Bertolla, F., Van Gijsegem, F., Nesme, X., and Simonet, P. 1997. Conditions for natural transformation of Ralstonia solanacearum. Appl. Environ. Microbiol. 63:4965-4968.

Boucher, C. A., Barberis, P., Trigalet, A. P., and Démery, D. A. 1985. Transposon mutagenesis of Pseudomonas solanacearum: Isolation of Tn5-induced avirulent mutants. J. Gen. Microbiol. 131:2449-2457.

Buchrieser, C., Rusniok, C., Kunst, F., Cossart, P., and Glaser, P. 2003. Comparison of the genome sequences of Listeria monocytogenes and Listeria innocua: clues for evolution and pathogenicity. FEMS (Fed. Eur. Microbiol. Soc.) Immunol. Med. Microbiol. 35:207-213.

Buddenhaggen, I., Sequeira, L., and Kelman, A. 1962. Designation of races in Pseudomonas solanacearum. (Abstr.) Phytopathology 52:726.

Buell, C. R., Joardar, V., Lindeberg, M., Selengut, J.. Paulsen, I. T., Gwinn, M. L., Dodson, R. J., Deboy, R. T., Durkin, A. S., Kolonay, J. F., Madupu, R., Daugherty, S., Brinkac, L., Beanan, M. J., Haft, D. H., Nelson, W. C., Davidsen, T., Zafar, N., Zhou, L., Liu, J., Yuan, Q., Khouri, H., Fedorova, N., Tran, B., Russell, D., Berry, K., Utterback, T., Van Aken, S. E., Feldblyum, T. V., D’Ascenzo, M., Deng, W. L., Ramos, A. R., Alfano, J. R., Cartinhour, S., Chatterjee, A. K., Delaney, T. P., Lazarowitz, S. G., Martin, G. B., Schneider, D. J., Tang, X., Bender, C. L., White, O., Fraser, C. M., and Collmer, A. 2003. The complete genome sequence of the Arabidopsis and tomato pathogen Pseudomonas syringae pv. tomato DC3000. Proc. Natl. Acad. Sci. U.S.A. 100:10181-10186.

Charity, J. C., Pak, K., Delwiche, C. F., and Hutcheson, S. W. 2003. Novel exchangeable effector loci associated with the Pseudomonas syringae hrp pathogenicity island: evidence for integron-like assembly from transposed gene cassettes. Mol. Plant-Microbe Interact. 16:495-507.

Ciesiolka, L. D., Hwin, T., Gearlds, J. D., Minsavage, G. V., Saenz, R., Bravo, M., Handley, V., Conover, S. M., Zhang, H., Caporgno, J., Phengrasamy, N. B., Toms, A. O., Stall, R. E., and Whalen, M. C. 1999. Regulation of expression of avirulence gene avrRxv and identification of a family of host interaction factors by sequence analysis of avrBsT. Mol. Plant-Microbe Interact. 12:35-44.

Cook, D., Barlow, E., and Sequeira, L. 1989. Genetic diversity of Pseudomonas solanacearum: detection of Restriction Fragment Length Polymorphisms with DNA probes that specify virulence and the Hypersensitive Response. Mol. Plant-Microbe Interact. 2:113-121.

Cook, D., and Sequeira, L. 1994. Strain differentiation of Pseudomonas solanacearum by molecular genetics methods. Pages 77-93 in: Bacterial Wilt: The Disease and Its Causative Agent Pseudomonas solanacearum. A. C. Hayward and G. L. Hartman, eds. CAB International, Wallingford, U.K.

Cunnac, S., Occhialini, A., Barberis, P., Boucher, C., and Genin, S. Inventory and functional analysis of the large Hrp regulon in Ralstonia solanacearum: identification of novel effector proteins translocated to plant host cells through the Type III secretion system. Mol. Microbiol. in press.

Da Silva, A. C., Ferro, J. A., Reinach, F. C., Farah, C. S., Furlan, L. R., Quaggio, R. B., Monteiro-Vitorello, C. B., Van Sluys, M. A., Almeida, N. F., Alves, L. M., do Amaral, A. M., Bertolini, M. C., Camargo, L. E., Camarotte, G., Cannavan, F., Cardozo, J., Chambergo, F., Ciapina, L. P., Cicarelli, R. M., Coutinho, L. L., Cursino-Santos, J. R., El Dorry, H., Faria, J. B., Ferreira, A. J., Ferreira, R. C., Ferro, M. I., Formighieri, E. F., Franco, M. C., Greggio, C. C., Gruber, A., Katsuyama, A. M., Kishi, L. T., Leite, R. P., Lemos, E. G., Lemos, M. V., Locali, E. C., Machado, M. A., Madeira, A. M., Martinez-Rossi, N. M., Martins, E. C., Meidanis, J., Menck, C. F., Miyaki, C. Y., Moon, D. H., Moreira, L. M., Novo, M. T., Okura, V. K., Oliveira, M. C., Oliveira, V. R., Pereira, H. A., Rossi, A., Sena, J. A., Silva, C., de Souza, R. F., Spinola, L. A., Takita, M. A., Tamura, R. E., Teixeira, E. C., Tezza, R. I., Trindade dos, S. M., Truffi, D., Tsai, S. M., White, F. F., Setubal, J. C., and Kitajima, J. P. 2002. Comparison of the genomes of two Xanthomonas pathogens with differing host specificities. Nature 417:459-463.

Deslandes, L., Olivier, J., Peeters, N., Feng, D. X., Khounlotham, M. Boucher, C., Somssich, I., Genin, S., and Marco, Y. 2003. Physical interaction between RRS1-R, a protein conferring resistance to bacterial wilt, and PopP2, a type III effector targeted to the plant nucleus. Proc. Natl. Acad. Sci. U.S.A. 100:8024-8029.

Deslandes, L., Pileur, F. , Liaubet, L., Camut, S., Can, C., Williams, K., Holub, E., Beynon, J., Arlat, M., and Marco, Y. 1998. Genetic characterization of RRS1, a recessive locus in Arabidopsis thaliana that confers resistance to the bacterial soilborne pathogen Ralstonia solanacearum. Mol. Plant-Microbe Interact. 11:659-667.

Ezra, D., Barash, I., Valinsky, L., and Manulis, S. 2000. The dual function in virulence and host range restriction of a gene isolated from the
pPATH (Ehg) plasmid of Erwinia herbicola pv. gypsophilae. Mol. Plant-Microbe Interact. 13:683-692.

Galtier, N., Gouy, M., and Gautier, C. 1996. SEAVIEW and PHYLO_WIN: two graphic tools for sequence alignment and molecular phylogeny. Comput. Appl. Biosci. 12:543-548.

Gillings, M., Fahy, P., and Davies, C. 1993. Restriction analysis of an amplified polygalacturonase gene fragment differentiates strains of the phytopathogenic bacterium Pseudomonas solanacearum. Lett. Appl. Microbiol. 17:44-48.

Gogarten, J. P., Doolittle, W. F., and Lawrence, J. G. 2002. Prokaryotic evolution in light of gene transfer. Mol. Biol. Evol. 19:2226-2238.

Gophna, U., Ron, E. Z., and Graur, D. 2003. Bacterial type III secretion systems are ancient and evolved by multiple horizontal-transfer events. Gene 312:151-163.

Guéneron, M., Timmers, A. C., Boucher, C., and Arlat, M. 2000. Two novel proteins, PopB, which has functional nuclear localization signals, and $\mathrm{PopC}$, which has a large leucine-rich repeat domain, are secreted through the hrp-secretion apparatus of Ralstonia solanacearum. Mol. Microbiol. 36:261-277.

Hacker, J., Hentschel, U., and Dobrindt, U. 2003. Prokaryotic chromosomes and disease. Science 301:790-793.

Hacker, J., and Kaper, J. B. 2000. Pathogenicity islands and the evolution of microbes. Annu. Rev. Microbiol. 54:641-679.

Hayward, A. C. 1964. Characteristics of Pseudomonas solanacearum. J. Appl. Bacteriol. 27:265-277.

Hayward, A. C. 1991. Biology and epidemiology of bacterial wilt caused by Pseudomonas solanacearum. Annu. Rev. Phytopathol. 29:65-87.

Hayward, A. C. 1994. Systematics and phylogeny of Pseudomonas solanacearum and related bacteria. Pages 123-135 in: Bacterial Wilt: The Disease and Its Causative Agent, Pseudomonas solanacearum. A. C. Hayward and G. L. Hartman, eds. CAB International, Wallingford, U.K.

He, L. Y., Sequeira, L., and Kelman, A. 1983. Characteristics of strains of Pseudomonas solanacearum. Plant Dis. 67:1357-1361.

Hutcheson, S. W. 1999. The hrp cluster of Pseudomonas syringae: A pathogenicity island encoding a type III protein translocation complex? Pages 309-329 in: Pathogenicity Islands and Other Mobile Virulence Elements. J. B. Kaper and J. Hacker, eds. American Society of Microbiology, Washington, D.C.

Jain, R., Rivera, M. C., Moore, J. E., and Lake, J. A. 2002. Horizontal gene transfer in microbial genome evolution. Theor. Popul. Biol. 61:489-495.

Jain, R., Rivera, M. C., Moore, J. E., and Lake, J. A. 2003. Horizontal gene transfer accelerates genome innovation and evolution. Mol. Biol. Evol. 20:1598-1602.

Johnson, D. R., Bathnagar, R. S., Knoll, L. J., and Gordon, J. I. 1994. Genetic and biochemical studies of protein N-myristoylation. Annu. Rev. Biochem. 63:869-914.

Lavie, M., Shillington, E., Eguiluz, C., Grimsley, N., and Boucher, C. 2002. PopP1, a new member of the YopJ/AvrRxv family of type III effector proteins, acts as a host-specificity factor and modulates aggressiveness of Ralstonia solanacearum. Mol. Plant-Microbe Interact. 15:1058-1068

Li, X., Dorsch, M., Del Dot, T., Sly, L. I., Stackebrandt, E., and Hayward, C. 1993. Phylogenetic studies of the rRNA group II pseudomonads based on 16S rRNA gene sequences. J. Appl. Bacteriol. 74:324-329.

Lindgren, P. B., Peet, R. C., and Panopoulos, N. J. 1986. Gene cluster of Pseudomonas syringae pv. "phaseolicola" controls pathogenicity of bean plants and hypersensitivity of non-host plants. J. Bacteriol. 168:512-522.

Liu, Y. G., and Whittier, R. F. 1995. Thermal asymmetric interlaced PCR: automatable amplification and sequencing of insert end fragments from P1 and YAC clones for chromosome walking. Genomics 25:674-681.

Marenda, M., Brito, B., Callard, D., Genin, S., Barberis, P., Boucher, C. and Arlat, M. 1998. PrhA controls a novel regulatory pathway required for the specific induction of Ralstonia solanacearum hrp genes in the presence of plant cells. Mol. Microbiol. 27:437-453.

Nimchuk, Z., Marois, E., Kjemtrup, S., Leister, R. T., Katagiri, F., and Dangl, J. L. 2000. Eukaryotic fatty acylation drives plasma membrane targeting and enhances function of several type III effector proteins from Pseudomonas syringae. Cell 101:353-363.

Ochman, H., Lawrence, J. G., and Groisman, E. A. 2000. Lateral gene transfer and the nature of bacterial innovation. Nature 405:299-304.

Orth, K. 2002. Function of the Yersinia effector YopJ. Curr. Opin. Microbiol. 5:38-43

Pegg, K. G., and Moffett, M. 1971. Host range of the ginger strain of Pseudomonas solanacearum in Queensland. Aust. J. Exp. Agric. Anim. Husb. 11:696-698.

Perna, N. T., Plunkett, G., III, Burland, V., Mau, B., Glasner, J. D., Rose, D. J., Mayhew, G. F., Evans, P. S., Gregor, J., Kirkpatrick, H. A., Posfai, 
G., Hackett, J., Klink, S., Boutin, A., Shao, Y., Miller, L., Grotbeck, E. J., Davis, N. W., Lim, A., Dimalanta, E. T., Potamousis, K. D., Apodaca, J., Anantharaman, T. S., Lin, J., Yen, G., Schwartz, D. C., Welch, R. A., and Blattner, F. R. 2001. Genome sequence of enterohaemorrhagic Escherichia coli O157:H7. Nature 409:529-533.

Poussier, S., Prior, P., Luisetti, J., Hayward, C., and Fegan, M. 2000a. Partial sequencing of the $h r p B$ and endoglucanase genes confirms and expands the known diversity within the Ralstonia solanacearum species complex. Syst. Appl. Microbiol. 23:479-486.

Poussier, S., Trigalet-Demery, D., Vandewalle, P., Goffinet, B., Luisetti, J., and Trigalet, A. 2000b. Genetic diversity of Ralstonia solanacearum as assessed by PCR-RFLP of the hrp gene region, AFLP and 16S rRNA sequence analysis, and identification of an African subdivision. Microbiology 146:1679-1692.

Poussier, S., Vandewalle, P., and Luisetti, J. 1999. Genetic diversity of African and worldwide strains of Ralstonia solanacearum as determined by PCR-restriction fragment length polymorphism analysis of the hrp gene region. Appl. Environ. Microbiol. 65:2184-2194.

Saitou, N., and Nei, M. 1987. The Neighbor joining method: a new method for reconstructing phylogenetic trees. Mol. Biol. Evol. 4:406-425.

Salanoubat, M., Genin, S., Artiguenave, F., Gouzy, J., Mangenot, S., Arlat, M., Billault, A., Brottier, P., Camus, J. C., Cattolico, L., Chandler, M., Choisne, N., Claudel-Renard, C., Cunnac, S., Demange, N., Gaspin, C., Lavie, M., Moisan, A., Robert, C., Saurin, W., Schiex, T., Siguier, P., Thebault, P., Whalen, M., Wincker, P., Levy, M., Weissenbach, J., and Boucher, C. A. 2002. Genome sequence of the plant pathogen Ralstonia solanacearum. Nature 415:497-502.

Sambrook, J., Fritsch, E. F., and Maniatis, T. 1989. Molecular Cloning: A
Laboratory Manual. 2nd ed. Cold Spring Harbor Laboratory Press, Cold Spring Harbor, NY, U.S.A.

Seal, S. E., Jackson, L. A., Young, J. P. W., and Daniels, M. J. 1993. Differentiation of Pseudomonas solanacearum, Pseudomonas syzygii, Pseudomonas pickettii and the Blood Disease Bacterium by partial $16 \mathrm{~S}$ rRNA sequencing: construction of oligonucleotides primers for sensitive detection by polymerase chain reaction. J. Gen. Microbiol. 139:1587-1594.

Shan, L., He, P., Zhou, J. M., and Tang, X. 2000. A cluster of mutations disrupt the avirulence but not the virulence function of AvrPto. Mol. Plant-Microbe Interact. 13:592-598.

Taghavi, M., Hayward, C., Sly, L. I., and Fegan, M. 1996. Analysis of the phylogenetic relationships of strains of Burkholderia solanacearum, Pseudomonas syzygii, and the blood disease bacterium of banana based on 16S rRNA gene sequences. Int. J. Syst. Bacteriol. 46:10-15.

Thompson, J. D., Gibson, T. J., Plewniak, F., Jeanmougin, F., and Higgins, D. G. 1997. The CLUSTAL_X windows interface: flexible strategies for multiple sequence alignment aided by quality analysis tools. Nucleic Acids Res. 25:4876-4882.

\section{AUTHOR-RECOMMENDED INTERNET RESOURCE}

North Carolina State UniversityBioedit biological sequence alignment editor website: www.mbio.ncsu.edu/BioEdit/bioedit.html

INRA web server Ralstonia solanacearum page: sequence.toulouse.inra.fr/R.solanacearum.html 